\title{
Genetic Variability, Heritability and Genetic Advance Among Bread Wheat Genotypes at Southeastern Ethiopia
}

\author{
Tilahun Bayisa ${ }^{1, *}$, Habtamu Tefera ${ }^{2}$, Tesfaye Letta ${ }^{3}$ \\ ${ }^{1}$ Sinana Agricultural Research Center, Oromia Agricultural Research Institute, Bale Robe, Ethiopia \\ ${ }^{2}$ Plant Science Department, College of Agricultural and Environmental Science, Haramaya University, Dire Dewa, Ethiopia \\ ${ }^{3}$ Oromia Agricultural Research Institute, Addis Abeba, Ethiopia
}

Email address:

tilahunbayisa@gmail.com (T. Bayisa), habmam21@gmail.com (H. Tefera), tesfayeletta@gmail.com (T. Letta)

${ }^{*}$ Corresponding author

\section{To cite this article:}

Tilahun Bayisa, Habtamu Tefera, Tesfaye Letta. Genetic Variability, Heritability and Genetic Advance Among Bread Wheat Genotypes at Southeastern Ethiopia. Agriculture, Forestry and Fisheries. Vol. 9, No. 4, 2020, pp. 128-134. doi: 10.11648/j.aff.20200904.15

Received: February 27, 2020; Accepted: June 12, 2020; Published: August 19, 2020

\begin{abstract}
The knowledge of nature and magnitude of variation existing in available breeding materials is great importance for successful selection of varieties. This study was conducted to generate information on the extent of genetic variability in advanced bread wheat lines. Thirty bread wheat genotypes were tested at Sinana and Agarfa, Southeastern Ethiopia, in alpha lattice design with three replications. Combined over locations ANOVA was carried out for yield and yield related traits. There were highly significant differences among genotypes for all traits. Highly significant location effects at $\mathrm{P}<0.01$ were observed for yield and yield related except for harvest index which showed significant effect at $\mathrm{P}<0.05$ and grain yield non-significant location effect. This indicates the presence of variability for these characters among the tested genotypes. In combined analysis, grain yield had high PCV (27.1\%) and moderate GCV was observed for biomass weight, grain yield and harvest index. Phenotypic coefficient of variance (PCV) moderate for biomass weight and harvest index. Heritability estimates in broad sense $\left(\mathrm{H}^{2}\right)$ was very high for most of the characters except for grain yield $(52.3 \%)$ and number of kernel per spike (73.2\%). However, low GAM was observed for most of the characters except moderate GAM was observed for harvest index $(15.9 \%)$. Finally, the presence of variability among the genotypes, performance of heritability and GAM in the tested traits of the genotypes confirmed possibility to increase wheat productivity. Hence, selection and hybridization on those genotypes can be recommended for farther yield improvement of bread wheat.
\end{abstract}

Keywords: Bread Wheat, Variability, Heritability, Genetic Advance, GCV, PCV

\section{Introduction}

Bread wheat, Triticum aestivum L. $(2 \mathrm{n}=6 \mathrm{x}=42$, AABBDD), belongs to the tribe Triticeae in the family Poaceae. Morphological, cytogenetic and molecular studies have shown that the genomic evolution of the segmental allohexaploid occurred through the hybridization of Triticum turgidum $\mathrm{L}$ tetraploid wheat (AABB) with wild relative (DD) - a grass Triticum tauschii followed by the doubling of chromosomes [1,2].

Ethiopia is leading wheat producer in Sub Saharan Africa and total production of 4.53 million tons [3]. Accordingly, Oromia National Regional State contributes a total production of 2.66 million tons in the country. Among the wheat producing zones of Oromia, Arsi, West Arsi and Bale are considered as the wheat belts of eastern Africa. Although the productivity of wheat has increased in the last few years in the country, it is still very low as compared to other wheat producing countries in other parts of the world. The national average of wheat productivity is estimated to be $2.68 \mathrm{t} \mathrm{ha}^{-1}$ [3], which is below the world average of $3.0 \mathrm{t} \mathrm{ha}^{-1}$ [4].

For a successful breeding program, the presence of genetic variability plays a vital role. The knowledge of nature and magnitude of variation existing in available breeding materials, inter relationships between quantitatively inherited traits on grain yield is of great importance for successful selection of varieties for yield $[5,6]$. Reduction in the genetic variability makes the crops increasingly vulnerable to diseases and adverse climatic changes [7]. Therefore, precise 
information on the nature and degree of genetic variability present in wheat would help to select parents for evolving superior varieties.

High genetic advancement together with high heritability estimates offers the most suitable condition for selection [8]. The presence of variability, heritability and genetic advance in different yield related characters of bread wheat has been reported by different authors such as [9-12]. However, no variability studies have been conducted for recent genotypes in the study area. The current study was designed to generate information on advanced bread wheat lines to assess the extent of genetic variability in advanced bread wheat lines.

\section{Materials and Methods}

\subsection{Description of Experimental Areas}

The experiment was conducted at Sinana Agricultural Research Centre (SARC) and Agarfa district in the 2017 main cropping season. Sinana Agricultural Research Centre is located in Bale Zone of Oromia National Regional State, Southeastern Ethiopia. It is situated at a distance of about 463 $\mathrm{km}$ away from Addis Ababa in the Southeastern direction, and $33 \mathrm{~km}$ from the nearby town, Robe-the capital city of the zone. Geographically, SARC is located at $07^{\circ} 07^{\prime} \mathrm{N}$ latitude and $40^{\circ} 10^{\prime} \mathrm{E}$ longitude at 2400 meter above sea level (m.a.s.l). The area is characterized by bimodal rainfall pattern and received annual total rainfall ranging from 750 to 1400 $\mathrm{mm}$. The main season locally called 'Bona season' which extends from August to December received 270 to $842 \mathrm{~mm}$ rainfall, while the short season 'Ganna' from March to June received from 250 to $562 \mathrm{~mm}$ rainfall annually. Mean annual minimum and maximum temperatures 9.6 and $20.7^{\circ} \mathrm{C}$, respectively. The soil texture of the area is clay loam having black color with $\mathrm{pH}$ ranges between 6.3-6.8 [13]. Agarfa is located at $07^{\circ} 26^{\prime} \mathrm{N}$ latitude and $39^{\circ} 87^{\prime} \mathrm{E}$ longitude with an elevation of 2510 m.a.s.l. Its total annual rainfall ranges from 1000 to $1451 \mathrm{~mm}$. The mean annual minimum and maximum temperatures 7.3 and $22.8^{\circ} \mathrm{C}$, respectively. The experiment at both locations was conducted during the main cropping season.

\subsection{Experimental Materials and Design}

The experimental materials comprised of thirty bread wheat genotypes including two released bread wheat varieties viz. Kingbird, Pavon-76 and 28 advanced bread wheat lines. These advanced lines are composed of materials introduced from CIMMYT, ICARDA and advanced genotypes generated from local crosses. The details of genotypes are summarized in Table 1. The experiment was laid out in alpha lattice design with three replications having plot size of six rows of $0.2 \mathrm{~m}$ spacing and $2.5 \mathrm{~m}$ length (total area of the plot was $3 \mathrm{~m}^{2}$ ). Four central rows were harvested for grain yield computations. Seed rate of $150 \mathrm{~kg} \mathrm{ha}^{-1}$ and fertilizer rates of $41 / 46 \mathrm{~N} / \mathrm{P}_{2} \mathrm{O}_{5}$ were used. Planting was done by hand drilling; weed was controlled by using hand weeding as well as by using herbicide called Pallas 45OD (Pyroxsulam Triazolopyrimidine) at the recommended rate of $0.51 \mathrm{ha}^{-1}$ at stage of 21 days after planting.

\subsection{Data Collection}

All yield and yield related data were recorded from the middle four rows of each experiment

unit. The following agronomic traits were included: Days to heading, days to maturity, grain filling period, plant height (cm), number of productive tillers, number of spikelets per spike, spike length $(\mathrm{cm})$, number of kernels per spike, biomass yield $\left(\mathrm{t} \mathrm{ha}^{-1}\right)$, grain yield at $12.5 \%$ moisture $\left(\mathrm{t} \mathrm{ha}^{-1}\right)$, harvest index $(\%)$, thousand kernel weight $(\mathrm{g})$ and hectoliter weight $\left(\mathrm{kg} \mathrm{hl}^{-1}\right)$.

Table 1. List of bread wheat genotypes along with their respective pedigrees and origin used at Sinana and Agarfa, Southeastern Ethiopia in 2017.

\begin{tabular}{|c|c|c|c|}
\hline $\mathbf{S} / \mathbf{N}$. & Genotype & Pedigree & Origin \\
\hline 1 & ETBW 8252 & SW895124*2/FASAN/3/ALTAR84/AESQ//2*OPATA/4/ARREHANE & CIMMYT \\
\hline 2 & ETBW 8064 & Line 1 Singh/ETBW4919 & KARC \\
\hline 3 & ETBW 8065 & Line 1 Singh/ETBW4919 & KARC \\
\hline 4 & ETBW 8066 & Line 1 Singh/ETBW4919 & KARC \\
\hline 5 & ETBW 8070 & Line 1 Singh/ETBW4919 & KARC \\
\hline 6 & ETBW 8145 & OPATA/RAYON//KAUZ/3/MILAN/DUCULA & ICARDA \\
\hline 7 & ETBW 8163 & SUDAN\#3/SHUHA-6//FLAG-5 & ICARDA \\
\hline 8 & ETBW 8290 & KACHU/KINDE & CIMMYT \\
\hline 9 & ETBW 8310 & ND643/2*WBLL1//ATTILA*2/PBW65/3/MUNAL & CIMMYT \\
\hline 10 & ETBW 8336 & PFAU/MILAN//ETBW 4921 & ICARDA \\
\hline 11 & ETBW 8342 & N-AZRAQ-3/ETBW 4921 & ICARDA \\
\hline 12 & ETBW 8348 & CMH82A1294/2*KAUZ//MUNIA/CHTO/3/MILAN/4/AMIR-2 & CIMMYT \\
\hline 13 & ETBW 8253 & SOKOLL*2/ROLF07 & CIMMYT \\
\hline 14 & ETBW 8265 & FRANCOLIN $\# 1 / 4 / 2 * B A B A X / L R 42 / / B A B A X * 2 / 3 / K U R U K U$ & CIMMYT \\
\hline 15 & ETBW 8280 & $\mathrm{SNLG} / 3 / \mathrm{EMB} 16 / \mathrm{CBRD} / / \mathrm{CBRD} / 4 / \mathrm{KA} / \mathrm{NAC} / / \mathrm{TRCH}$ & CIMMYT \\
\hline 16 & ETBW 8283 & KA/NAC//TRCH/3/DANPHE \#1 & CIMMYT \\
\hline 17 & ETBW 8287 & CNO79//PF70354/MUS/3/PASTOR/4/BAV92*2/5/HAR311 & CIMMYT \\
\hline 18 & ETBW 8292 & KACHU/KIRITATI & CIMMYT \\
\hline 19 & ETBW 8359 & ALMAZ-11/3/PASTOR/FLORKWA-1//PASTOR & ICARDA \\
\hline 20 & ETBW 8362 & JAWAHIR-2//MILAN/DUCULA & CIMMYT \\
\hline 21 & ETBW 8309 & SUP $152 * 2 /$ KIRITATI & CIMMYT \\
\hline 22 & ETBW 8206 & FARIS-17//PFAU/MILAN & ICARDA \\
\hline
\end{tabular}




\begin{tabular}{llll}
\hline S/N. & Genotype & Pedigree & Origin \\
\hline 23 & ETBW 8304 & FRNCLN/4/WHEAR/KUKUNA/3/C80.1/3*BATAVIA//2*WBLL1 & ICARDA \\
24 & ETBW 8338 & HUBARA-5/ETBW 4922 & ICARDA \\
25 & ETBW 8411 & CHAM-4/MUBASHIIR-9 & CIMMYT \\
26 & ETBW 8445 & HAAMA-16/MILAN & CIMMYT \\
27 & ETBW 8441 & TURACO/CHIL/6/SERI82/5/ALD'S/4/BB/GLL/CNO67/7C/3/KUZ/TI & ICARDA \\
28 & ETBW 8451 & FLAG-6/ICARDA-SRRL-6 & ICARDA \\
29 & Kingbird & THELIN \# 2/TUKURU & KARC \\
30 & Pavon 76 & VCM/CNO/7C/3/KAL/BB & KARC \\
\hline
\end{tabular}

$\mathrm{KARC}=$ Kulumsa Agricultural Research Center; CIMMYT $=$ International Maize and Wheat Improvement Center; and ICARDA $=$ International Center for Agricultural Research in the Dry Areas.

\subsection{Statistical Data Analysis}

All measured parameters including yield and yield related parameters were subjected to analysis of variance (ANOVA) following standard procedures using Proc Lattice and Proc GLM of SAS version 9.2 statistical software to estimate the prevailing variation among tested genotypes. Mean separation was carried out using Duncan's Multiple Range Test (DMRT) at 5 percent levels of significance depending on the significance of the analysis of variance for each traits.

\subsubsection{Estimation of Magnitude of Variance Component}

The phenotypic and genotypic variation at each location was estimated according to the method suggested by [14].

$$
\sigma_{g}^{2}=\frac{M S_{g}-M_{e}}{r}
$$

For combined location $\sigma_{g}^{2}=\frac{M S_{g l}-M S_{e}}{r l}$

$$
\sigma_{g x e}^{2}=\frac{M S_{g x e}-M S_{e}}{r \quad \text { for genotype x location }}
$$

Phenotypic variance $\left(\sigma_{p}^{2}\right)=\sigma_{g}^{2}+\frac{\sigma_{g x e}^{2}}{l}+\frac{M S e}{r l}$

Where, $\boldsymbol{\sigma}_{g}^{2}=$ Genotypic variance

$$
\sigma_{p}^{2}=\text { Phenotypic variance }
$$

$\sigma_{g x e}^{2}=$ Genotypic by environment variance

$M S_{g}=$ Mean square due to genotypes

$M_{e}=$ Environmental variation (error mean square)

$$
\sigma_{p}^{2}=\sigma_{g}^{2}+\sigma_{e}^{2}
$$

$r=$ Number of replications

Coefficient of variation at phenotypic levels was estimated using the following formulae:

$$
\begin{gathered}
P C V=\frac{\sqrt{\text { phenotypic var iance }}}{\text { population mean for the character }} \times 100 \\
G C V=\frac{\sqrt{\text { genotypic var iance }}}{\text { population mean for the character }} \times 100
\end{gathered}
$$

\subsubsection{Estimate of Heritability and Expected Genetic Advance}

Heritability $\left(\mathrm{H}^{2}\right)$ in broad sense was computed for yield and yield related traits using the formula adopted from [15] as follow:

$$
\mathrm{H}^{2}=\left[\sigma_{\mathrm{g}}^{2} / \sigma_{\mathrm{p}}^{2}\right] \times 100
$$

Where: $\sigma_{\mathrm{g}}^{2}=$ genotypic variance

$\sigma_{\mathrm{p}}^{2}=$ phenotypic variance

$\sigma_{\mathrm{e}}^{2}=$ error variance

Genetic advance (GA) for each character was computed using the formula adopted from $[8,15]$.

$$
\begin{gathered}
\mathrm{GA}=(\mathrm{k})\left(\sigma_{\mathrm{p}}\right)\left(\mathrm{H}^{2}\right) \\
\mathrm{GA}(\text { as } \% \text { of the mean })=\frac{G A}{X} \times 100
\end{gathered}
$$

Where, $\mathrm{k}=$ selection differential $(\mathrm{k}=2.06$ at $5 \%$ selection intensity)

$\sigma_{\mathrm{p}}=$ phenotypic standard deviation

$\mathrm{H}^{2}=$ heritability (Broad sense) $\mathrm{X}=$ Grand mean

\section{Results and Discussion}

\subsection{Analysis of Variance}

The relative efficiency of alpha lattice design for most of the character was greater and $\mathrm{CV}$ value less than RCBD, this indicating that alpha lattice has advantage in increasing experimental precision. As $[10,16]$ reported the same in that alpha lattice design was more efficient in reducing the experimental error and hence provided the efficient estimation of treatment effects. Test of homogeneity of error variance showed that the error mean squares were homogeneous for most traits except number of spiklet per spike and number of productive tiller. Hence, combined data analysis was done for homogeneous characters.

Combined ANOVA across locations were carried out for all characters of yield and yield related traits (Table 2). There was a highly significant at $P<0.01$ for all traits among the 
test genotypes. This indicated the presence of sufficient genetic variability for yield and yield related traits among the genotypes tested. Similarly, variability among wheat genotypes for yield and yield related traits reported by [10, 11, 17]. However, [18] found non-significant differences among genotypes for plant height and number of tillers per plant.

Highly significant $(P<0.01)$ location effects were observed for all yield related traits and grain yield had nonsignificant location effect. This might be due to differences in growth conditions exhibited at the two locations. The genotype $\mathrm{x}$ environment interaction showed highly significant $(P<0.01)$ differences among wheat genotypes for days to heading, days to maturity, biomass weight, grain yield, harvest index, and Significant $(P<0.05)$ genotypic $\mathrm{x}$ environment interaction was found for grain filling period, plant height and number of kernel per spike (Table 2). Genotypes responded differently to varying environments for these traits. This suggested that the importance of assessment of genotypes under different environments in order to identify better performing genotypes show better performance across locations and analysis was done for individual locations.

Table 2. Combined analysis of yield and yield related traits in bread wheat genotypes tested at Sinana and Agarfa, Southeastern Ethiopia in 2017.

\begin{tabular}{|c|c|c|c|c|c|c|c|c|}
\hline \multirow{2}{*}{ Traits } & \multicolumn{6}{|c|}{ Source of Variation } & \multirow{2}{*}{ Mean } & \multirow{2}{*}{$\mathrm{CV}$} \\
\hline & Loc [1] & $\operatorname{Rep}(\operatorname{Loc})[4]$ & Block (Loc x Rep) [30] & Genotype [29] & Genotype x Loc [29] & Error $[86]$ & & \\
\hline DH & $45.0 * *$ & $8.98 * *$ & $2.70^{*}$ & $56.81 * *$ & $5.75 * *$ & 1.45 & 68.72 & 1.75 \\
\hline DM & $10672.2 * *$ & $11.56^{*}$ & $7.04^{\mathrm{ns}}$ & $72.42^{* *}$ & $10.48 * *$ & 4.48 & 130.15 & 1.63 \\
\hline Gfp & $12103.2 * *$ & $5.77^{\mathrm{ns}}$ & $7.88 *$ & $45.54 * *$ & $7.12 *$ & 4.36 & 61.43 & 3.40 \\
\hline Plh & $932.07 * *$ & $31.44 *$ & $31.71^{* *}$ & $86.64 * *$ & $18.00 *$ & 10.44 & 86.24 & 3.75 \\
\hline SPL & $78.83 * *$ & $0.91 *$ & $0.71 * *$ & $2.30^{* *}$ & $0.33^{\mathrm{ns}}$ & 0.34 & 7.93 & 7.32 \\
\hline NKPS & $3853.09 * *$ & $91.43 * *$ & $15.64^{\mathrm{ns}}$ & $59.65^{* *}$ & $18.21 *$ & 9.86 & 36.94 & 8.50 \\
\hline BMW & $13.61 * *$ & $7.06 * *$ & $1.59^{\mathrm{ns}}$ & $17.77 * *$ & $3.68 * *$ & 1.24 & 11.46 & 9.73 \\
\hline GY & $0.15^{\mathrm{ns}}$ & $0.11^{\mathrm{ns}}$ & $0.096^{\mathrm{ns}}$ & $5.25 * *$ & $0.44 * *$ & 2.44 & 3.49 & 10.38 \\
\hline HI & $69.44 *$ & $17.13^{\text {ns }}$ & $16.26^{\mathrm{ns}}$ & $187.18 * *$ & $30.83^{* *}$ & 12.83 & 30.02 & 11.93 \\
\hline Hlw & $208.87 * *$ & $10.13^{\text {ns }}$ & $12.17^{\mathrm{ns}}$ & $64.99 * *$ & $13.47^{\mathrm{ns}}$ & 10.85 & 79.18 & 4.16 \\
\hline
\end{tabular}

$\mathrm{DH}=$ days to heading, $\mathrm{DM}=$ days to maturity, Gfp $=$ grain filling period, $\mathrm{Plh}=$ plant height, $\mathrm{SPL}=$ spike length in centimeter, NKPS $=$ number of kernel per spike, $\mathrm{BMW}=$ biomass weight ton per hectare, $\mathrm{GY}=$ grain yield in ton per hectare, $\mathrm{HI}=$ harvest index in percentage, $\mathrm{Hlw}=$ hectoliter weight, Loc $=$ location, Rep $=$ replication, Block $=$ block with in replication, Error $=$ error mean square, ${ }^{* *}=$ highly significant at $P<0.01,{ }^{*}=$ significant at $P<0.05$, ns $=$ no significant difference, Numbers in square bracket indicates degree of freedom.

\subsection{Performance of Genotypes for Yield and Yield Related Traits}

The combined analysis of range, mean and standard error of the mean values for 10 yield and yield related characters of 30 genotypes evaluated across locations were presented in Table 4. The detail mean performances of each genotypes for these characters based on combined over location analysis are presented in Table 3. Accordingly, the mean of days to heading, days to maturity and grain filling period were ranged from 61 to 74,125 to 137 and 51 to 61 , respectively. Comparable ranges of results also reported by [19] for days to heading (54-69), days to mature (106-129) and grain filling period (49-64). However, the current results obtained here are in contrast with the wide variation reported by $[9$, 12].

Plant height showed highly significant $(P<0.01)$ variability among the genotypes, which ranged from 77.9 to $97.2 \mathrm{~cm}$ with the mean value of $86.2 \mathrm{~cm}$ and coefficient of variation of $3.75 \%$ (Table 3 ). The shortest plant height (77.9 $\mathrm{cm}$ ) was observed from genotype ETBW 8163, while ETBW $8411(97.2 \mathrm{~cm})$ was the tallest genotype followed by ETBW $8283(91.4 \mathrm{~cm})$ and ETBW $8064(91.2 \mathrm{~cm})$, which is comparable to result reported by [9]. The magnitude of genetic variability for spike length was ranged from 6.4 to $9.1 \mathrm{~cm}$ with mean value of $7.9 \mathrm{~cm}$. Maximum $(9.1 \mathrm{~cm})$ spike length was measured for genotype ETBW 8336, while minimum was from ETBW 8445, which was only $6.4 \mathrm{~cm}$.

Combined analysis result was showed also highly significant variability among genotypes for grain yield $\mathrm{tha}^{-1}$, which ranged from 0.7 to $5.1 \mathrm{t} \mathrm{ha}^{-1}$ with the mean value of $3.5 \mathrm{t} \mathrm{ha}^{-1}$. From this result, ETBW $8338\left(5.1 \mathrm{t} \mathrm{ha}^{-1}\right)$ was gave the highest overall grain yield, followed by ETBW 8304 (4.8 $\left.\mathrm{t} \mathrm{ha}^{-1}\right)$ and ETBW $8342\left(4.7 \mathrm{t} \mathrm{ha}^{-1}\right)$. On the other hand genotype ETBW 8163 was gave the lowest $\left(0.7 \mathrm{t} \mathrm{ha}^{-1}\right)$ grain yield followed by genotype ETBW 8070 (1.37 $\left.\mathrm{t} \mathrm{ha}^{-1}\right)$ and genotype ETBW $8362\left(1.67 \mathrm{t} \mathrm{ha}^{-1}\right)$ (Table 3). Highly significant difference $(P<0.01)$ was observed among the test genotypes for biomass weight per hectare with the values that ranged from $7.0 \mathrm{t} \mathrm{ha}^{-1}$ (ETBW 8163) to $14.8 \mathrm{t} \mathrm{ha}^{-1}$ (ETBW 8338) with mean value of $11.5 \mathrm{t} \mathrm{ha}^{-1}$. The highest biomass weight was obtained from genotype ETBW 8338 followed by genotypes ETBW 8253 (14.4 $\left.\mathrm{t} \mathrm{ha}^{-1}\right)$ and ETBW 8283 (14.1 t $\left.\mathrm{ha}^{-1}\right)$, whereas the second and third minimum was obtained from genotype ETBW 8070 and ETBW $83097.1 \mathrm{t} \mathrm{ha}^{-1}$ and $8.7 \mathrm{t} \mathrm{ha}^{-1}$, respectively. Harvest index exhibited highly significant difference $(P<0.01)$ among genotypes with the value ranging from $9.2 \%$ (ETBW 8163 ) to $37.2 \%$ (ETBW 8304 ) with mean of $30.0 \%$. Combined analysis over locations for hectoliter weight ranged from 66.8 for genotype ETBW 8163 to 83.5 for genotype ETBW 8441 with the mean value of 79.2 .

\subsection{Phenotypic and Genotypic Variance of Yield and Yield Related Traits}

The amount of genotypic and phenotypic variability that exist in a species is most importance in breeding to select 
better varieties and initiating a breeding program. Genotypic and phenotypic coefficients of variation are used to measure the variability that exists in a given genotypes. Estimated genotypic coefficient of variability (GCV) and phenotypic coefficient of variability (PCV), for combined locations are presented in Tables 4.

Table 3. Mean performance of 30 bread wheat genotypes for different parameters across locations at Sinana and Agarafa, Southeastern Ethiopia in 2017.

\begin{tabular}{|c|c|c|c|c|c|c|c|c|c|c|}
\hline Treatment & DH & DM & Gfp & Plh & SPL & NKPS & BMW & GY & HI & HLw \\
\hline ETBW 8280 & $70^{\mathrm{c}-\mathrm{g}}$ & $130^{\mathrm{e}-\mathrm{g}}$ & $60^{\mathrm{f}-\mathrm{h}}$ & $85.2^{\mathrm{e}-\mathrm{h}}$ & $8.8^{\mathrm{a}-\mathrm{c}}$ & $38.5^{\mathrm{c}-\mathrm{e}}$ & $11.8^{\mathrm{d}-\mathrm{h}}$ & $3.7^{\mathrm{g}-\mathrm{i}}$ & $31.5^{\mathrm{b}-\mathrm{d}}$ & $81.2^{\mathrm{ab}}$ \\
\hline ETBW 8310 & $72^{\mathrm{bc}}$ & $135^{\mathrm{a}-\mathrm{c}}$ & $63^{\mathrm{b}-\mathrm{f}}$ & $83.9^{\mathrm{g}-\mathrm{j}}$ & $9.1^{\mathrm{a}}$ & $35.2^{\mathrm{e}-\mathrm{k}}$ & $12.5^{\mathrm{c}-\mathrm{f}}$ & $3.4^{\mathrm{h}}$ & $27.4^{\mathrm{d}-\mathrm{f}}$ & $75.1^{\mathrm{e}-\mathrm{h}}$ \\
\hline ETBW 8064 & $70^{\mathrm{e}-\mathrm{f}}$ & $127^{\mathrm{i}-\mathrm{l}}$ & $57^{\mathrm{ij}}$ & $91.2^{\mathrm{bc}}$ & $8.6^{\mathrm{a}-\mathrm{d}}$ & $35.3^{\mathrm{e}-\mathrm{k}}$ & $10.0^{\mathrm{i}-\mathrm{m}}$ & $2.8^{\mathrm{kl}}$ & $27.6^{\mathrm{d}-\mathrm{f}}$ & $71.2^{\text {hi }}$ \\
\hline ETBW 8163 & $74^{\mathrm{a}}$ & $130^{\mathrm{f}-\mathrm{h}}$ & $56^{\mathrm{j}}$ & $77.9^{1}$ & $7.4^{\mathrm{g}-\mathrm{i}}$ & $28.9^{1}$ & $7.0^{\mathrm{n}}$ & $0.7^{\circ}$ & $9.2^{\mathrm{h}}$ & $73.0^{\mathrm{g}-\mathrm{i}}$ \\
\hline ETBW 8451 & $71^{\mathrm{b}-\mathrm{e}}$ & $127^{\mathrm{h}-1}$ & $56^{\mathrm{j}}$ & $82.7^{\mathrm{h}-\mathrm{k}}$ & $7.4^{\mathrm{g}-\mathrm{i}}$ & $35.6^{\mathrm{e}-\mathrm{k}}$ & $11.0^{\mathrm{f}-\mathrm{j}}$ & $2.9^{\mathrm{jk}}$ & $26.7^{\mathrm{ef}}$ & $77.9^{\mathrm{a}-\mathrm{f}}$ \\
\hline ETBW 8309 & $69^{h-j}$ & $133^{\mathrm{b}-\mathrm{d}}$ & $65^{\mathrm{a}-\mathrm{c}}$ & $86.2^{\mathrm{d}-\mathrm{h}}$ & $7.6^{\mathrm{f}-\mathrm{i}}$ & $34.5^{\mathrm{f}-\mathrm{k}}$ & $8.7^{\mathrm{m}}$ & $2.4^{1}$ & $28.9^{\mathrm{c}-\mathrm{f}}$ & $75.5^{\mathrm{d}-\mathrm{h}}$ \\
\hline ETBW 8362 & $66^{\mathrm{kl}}$ & $127^{\mathrm{i}-\mathrm{l}}$ & $60^{\mathrm{f}-\mathrm{h}}$ & $87.1^{\mathrm{b}-\mathrm{h}}$ & $7.6^{\mathrm{f}-\mathrm{i}}$ & $36.3^{\mathrm{d}-\mathrm{k}}$ & $9.3^{\mathrm{k}-\mathrm{m}}$ & $1.6^{\mathrm{mn}}$ & $17.6^{\mathrm{g}}$ & $70.7^{\mathrm{i}}$ \\
\hline ETBW 8336 & $72^{\mathrm{b}-\mathrm{d}}$ & $136^{\mathrm{ab}}$ & $64^{\mathrm{a}-\mathrm{c}}$ & $86.5^{\mathrm{d}-\mathrm{h}}$ & $9.1^{\mathrm{a}}$ & $35.9^{-\mathrm{k}}$ & $13.1^{\mathrm{b}-\mathrm{d}}$ & $3.5^{\mathrm{g}-\mathrm{i}}$ & $27.1^{\mathrm{d}-\mathrm{f}}$ & $78.8^{\mathrm{a}-\mathrm{f}}$ \\
\hline ETBW 8253 & $73^{\mathrm{ab}}$ & $136^{\mathrm{ab}}$ & $63^{\mathrm{a}-\mathrm{f}}$ & $87.9^{\mathrm{b}-\mathrm{g}}$ & $7.9^{\mathrm{d}-\mathrm{h}}$ & $38.1^{\mathrm{b}-\mathrm{g}}$ & $14.4^{\mathrm{ab}}$ & $4.6^{\mathrm{bc}}$ & $31.6^{\mathrm{cd}}$ & $80.0^{\mathrm{a}-\mathrm{d}}$ \\
\hline ETBW 8265 & $73^{\mathrm{ab}}$ & $137^{\mathrm{a}}$ & $64^{\mathrm{a}-\mathrm{c}}$ & $83.6^{\mathrm{g}-\mathrm{j}}$ & $7.6^{\mathrm{f}-\mathrm{i}}$ & $37.5^{\mathrm{d}-\mathrm{i}}$ & $13.3^{\mathrm{b}-\mathrm{d}}$ & $4.0^{\mathrm{d}-\mathrm{g}}$ & $30.5^{\text {b-e }}$ & $79.6^{\mathrm{a}-\mathrm{e}}$ \\
\hline ETBW 8287 & $71^{\mathrm{b}-\mathrm{f}}$ & $127^{\mathrm{h}-\mathrm{l}}$ & $56^{\mathrm{j}}$ & $89.2^{\mathrm{b}-\mathrm{e}}$ & $7.4^{\mathrm{g}-\mathrm{i}}$ & $41.1^{\mathrm{bc}}$ & $12.2^{\mathrm{d}-\mathrm{g}}$ & $4.0^{\mathrm{d}-\mathrm{g}}$ & $33.0^{\mathrm{a}-\mathrm{c}}$ & $80.4^{\mathrm{a}-\mathrm{c}}$ \\
\hline ETBW 8342 & $71^{\mathrm{b}-\mathrm{f}}$ & $129^{f-i}$ & $58^{\mathrm{h}-\mathrm{j}}$ & $87.4^{\mathrm{b}-\mathrm{h}}$ & $7.3^{\mathrm{g}-\mathrm{i}}$ & $35.6^{\mathrm{d}-\mathrm{k}}$ & $13.3^{\mathrm{b}-\mathrm{d}}$ & $4.7^{\mathrm{ab}}$ & $35.6^{\mathrm{ab}}$ & $79.3^{\mathrm{a}-\mathrm{e}}$ \\
\hline ETBW 8445 & $70^{\mathrm{d}-\mathrm{h}}$ & $127^{\mathrm{h}-1}$ & $57^{\mathrm{ij}}$ & $78.8^{\mathrm{kl}}$ & $6.4^{\mathrm{j}}$ & $33.1^{\mathrm{i}-\mathrm{k}}$ & $12.2^{\mathrm{d}-\mathrm{g}}$ & $4.0^{\mathrm{d}-\mathrm{g}}$ & $33.2^{\mathrm{a}-\mathrm{c}}$ & $82.1^{\mathrm{a}}$ \\
\hline ETBW 8065 & $68^{\mathrm{h}-\mathrm{j}}$ & $133^{\mathrm{c}-\mathrm{e}}$ & $64^{\mathrm{a}-\mathrm{c}}$ & $83.7^{\mathrm{g}-\mathrm{j}}$ & $8.6^{\mathrm{a}-\mathrm{d}}$ & $38.4^{\text {b-f }}$ & $9.7^{\mathrm{j}-\mathrm{m}}$ & $2.4^{1}$ & $25.3^{f}$ & $76.3^{\mathrm{d}-\mathrm{g}}$ \\
\hline ETBW 8145 & $69^{g-j}$ & $131^{\mathrm{d}-\mathrm{f}}$ & $62^{\mathrm{c}-\mathrm{g}}$ & $88.1^{\mathrm{b}-\mathrm{g}}$ & $8.9^{\mathrm{ab}}$ & $39.1^{\text {b-e }}$ & $11.5^{\mathrm{e}-\mathrm{i}}$ & $3.9^{\mathrm{e}-\mathrm{g}}$ & $34.4^{\mathrm{ab}}$ & $79.3^{\mathrm{a}-\mathrm{e}}$ \\
\hline Pavon-76 & $68^{\mathrm{jk}}$ & $126^{\mathrm{kl}}$ & $58^{\mathrm{h}-\mathrm{j}}$ & $86.5^{\mathrm{c}-\mathrm{g}}$ & $8.0^{\mathrm{c}-\mathrm{h}}$ & $37.9^{\mathrm{c}-\mathrm{h}}$ & $10.0^{\mathrm{i}-\mathrm{m}}$ & $2.0^{\mathrm{m}}$ & $19.9^{\mathrm{g}}$ & $79.3^{\mathrm{a}-\mathrm{e}}$ \\
\hline ETBW 8206 & $71^{\mathrm{c}-\mathrm{g}}$ & $135^{\mathrm{a}-\mathrm{c}}$ & $65^{\mathrm{a}-\mathrm{c}}$ & $83.3^{\mathrm{g}-\mathrm{j}}$ & $7.2^{\mathrm{hi}}$ & $41.1^{\mathrm{bc}}$ & $12.5^{\mathrm{c}-\mathrm{e}}$ & $4.3^{\mathrm{b}-\mathrm{e}}$ & $34.6^{\mathrm{ab}}$ & $79.1^{\mathrm{a}-\mathrm{e}}$ \\
\hline ETBW 8411 & $63^{\mathrm{m}}$ & $126^{\mathrm{j}-1}$ & $63^{\mathrm{a}-\mathrm{e}}$ & $97.2^{\mathrm{a}}$ & $8.0^{\mathrm{c}-\mathrm{h}}$ & $35.6^{\mathrm{d}-\mathrm{k}}$ & $13.0^{\mathrm{b}-\mathrm{e}}$ & $4.4^{\mathrm{b}-\mathrm{d}}$ & $34.9^{\mathrm{ab}}$ & $79.3^{\mathrm{a}-\mathrm{f}}$ \\
\hline ETBW 8292 & $69^{g-j}$ & $129^{\mathrm{f}-\mathrm{i}}$ & $60^{\mathrm{e}-\mathrm{h}}$ & $89.5^{\text {b-e }}$ & $8.5^{\mathrm{a}-\mathrm{e}}$ & $46.9^{\mathrm{a}}$ & $11.9^{\mathrm{d}-\mathrm{h}}$ & $3.7^{\text {gh }}$ & $31.7^{\mathrm{b}-\mathrm{d}}$ & $81.2^{\text {ab }}$ \\
\hline ETBW 8066 & $66^{1}$ & $129^{\mathrm{f}-\mathrm{i}}$ & $63^{\mathrm{a}-\mathrm{e}}$ & $91.0^{\mathrm{bc}}$ & $7.7^{\mathrm{e}-\mathrm{i}}$ & $37.6^{\mathrm{c}-\mathrm{h}}$ & $12.6^{\mathrm{c}-\mathrm{e}}$ & $4.4^{\mathrm{b}-\mathrm{e}}$ & $34.8^{\mathrm{ab}}$ & $78.7^{\mathrm{a}-\mathrm{f}}$ \\
\hline ETBW 8359 & $66^{1}$ & $126^{\mathrm{kl}}$ & $60^{\mathrm{e}-\mathrm{h}}$ & $79.9^{\mathrm{i}-1}$ & $7.7^{\mathrm{e}-\mathrm{i}}$ & $33.6^{\mathrm{g}-\mathrm{k}}$ & $9.7^{1-\mathrm{m}}$ & $3.3^{\mathrm{ij}}$ & $34.2^{\mathrm{ab}}$ & $75.6^{\mathrm{c}-\mathrm{h}}$ \\
\hline ETBW 8070 & $68^{\mathrm{ij}}$ & $128^{\mathrm{g}-\mathrm{k}}$ & $60^{\mathrm{e}-\mathrm{h}}$ & $84.3 \mathrm{f}-\mathrm{i}$ & $7.3^{\mathrm{g}-\mathrm{i}}$ & $33.0^{\mathrm{jk}}$ & $7.1^{\mathrm{n}}$ & $1.3^{\mathrm{n}}$ & $18.4^{\mathrm{g}}$ & $77.1^{\mathrm{b}-\mathrm{g}}$ \\
\hline ETBW 8283 & $70^{\mathrm{e}-\mathrm{i}}$ & $135^{\mathrm{a}-\mathrm{c}}$ & $66^{\mathrm{ab}}$ & $91.4^{\mathrm{b}}$ & $8.0^{\mathrm{c}-\mathrm{h}}$ & $37.3^{\mathrm{c}-\mathrm{j}}$ & $14.1^{\mathrm{a}-\mathrm{c}}$ & $4.6^{\mathrm{bc}}$ & $32.6^{\mathrm{a}-\mathrm{c}}$ & $81.7^{\mathrm{ab}}$ \\
\hline ETBW 8290 & $61^{\mathrm{n}}$ & $125^{1}$ & $64^{\mathrm{a}-\mathrm{c}}$ & $88.8^{\mathrm{b}-\mathrm{f}}$ & $8.4^{\mathrm{a}-\mathrm{f}}$ & $40.1^{b-d}$ & $10.8^{\mathrm{g}-\mathrm{k}}$ & $3.9^{\mathrm{d}-\mathrm{g}}$ & $36.8^{\mathrm{a}}$ & $81.2^{\mathrm{ab}}$ \\
\hline ETBW 8441 & $70^{\mathrm{f}-\mathrm{j}}$ & $130^{\mathrm{e}-\mathrm{g}}$ & $61^{\mathrm{d}-\mathrm{h}}$ & $79.4^{\mathrm{j}-1}$ & $8.1^{\mathrm{c}-\mathrm{h}}$ & $33.2^{\mathrm{h}-\mathrm{k}}$ & $10.6^{\mathrm{h}-\mathrm{k}}$ & $3.8^{\mathrm{f}-\mathrm{h}}$ & $37.0^{\mathrm{a}}$ & $81.6^{\mathrm{ab}}$ \\
\hline ETBW 8304 & $69^{g-j}$ & $132^{\mathrm{d}-\mathrm{f}}$ & $63^{\mathrm{b}-\mathrm{g}}$ & $90.2^{\mathrm{b}-\mathrm{d}}$ & $8.8^{\mathrm{a}-\mathrm{c}}$ & $33.6^{\mathrm{g}-\mathrm{k}}$ & $12.9^{\mathrm{b}-\mathrm{e}}$ & $4.8^{\mathrm{ba}}$ & $37.2^{\mathrm{a}}$ & $79.1^{\mathrm{a}-\mathrm{f}}$ \\
\hline ETBW 8338 & $69^{h-j}$ & $135^{\mathrm{a}-\mathrm{c}}$ & $66^{\mathrm{a}}$ & $85.0^{\mathrm{e}-\mathrm{h}}$ & $6.9^{\mathrm{ij}}$ & $41.3^{b}$ & $14.8^{\mathrm{a}}$ & $5.1^{\mathrm{a}}$ & $34.7^{\mathrm{ab}}$ & $80.1^{\mathrm{a}-\mathrm{d}}$ \\
\hline Mean & 68.7 & 130.2 & 61.4 & 86.2 & 7.9 & 36.9 & 11.5 & 3.49 & 30.0 & 78.1 \\
\hline $\mathrm{CV}$ & 1.95 & 1.67 & 3.68 & 4.02 & 7.81 & 8.73 & 10.25 & 10.03 & 12.1 & 3.15 \\
\hline
\end{tabular}

$\mathrm{DH}=$ days to heading, $\mathrm{DM}=$ days to maturity, $\mathrm{Gfp}=$ grain filling period, $\mathrm{Plh}=$ plant height, $\mathrm{SPL}=$ spike length in centimeter, NKPS $=$ number of kernel per spike, $\mathrm{BMW}=$ biomass weight ton per hectare, $\mathrm{GY}=$ grain yield in ton per hectare, $\mathrm{HI}=$ harvest index in percentage.

The genotypic coefficient of variance (GCV) value for yield and yield related traits for combined location ranged from $2.6 \%$ for days to maturity to $19.6 \%$ for grain yield whereas the PCV values ranged from $2.8 \%$ for days to maturity to $27.1 \%$ for grain yield. Phenotypic coefficient of variance was generally higher than GCV for all traits studied at both location and combined locations, though the magnitude of the differences were small for most of the traits, indicating that the environmental effect on the expression of most characters was minimum. As [10, 20, 21] reported similar result for all studied character. According to [22], GCV and PCV can be categorized as high $(>20 \%)$, moderate $(10-20 \%)$ and low $(<10 \%)$. As per this category, for combined location, grain yield had high PCV (27.1\%). Moderate GCV was observed for biomass weight (14.5\%), grain yield (19.6\%) and harvest index (15.2\%). Phenotypic coefficient of variance moderate for biomass weight (16.0\%) and Harvest index (16.9\%). Low GCV and PCV was observed for days to heading $(4.4 \%$ and $4.6 \%)$, days to mature $(2.6 \%$ and $2.8 \%)$, grain filling period $(4.3 \%$ and $4.6 \%)$, plant height $(4.1 \%$ and $4.6 \%)$, spike length $(7.2 \%$ and $7.8 \%)$, number of kernel per spike $(7.8 \%$ and $9.1 \%)$ and hectoliter $(3.8 \%$ and $4.2 \%)$. The result agreed with the finding of $[10,21,23]$.

\subsection{Estimates of Heritability in Broad Sense}

Heritability estimates in broad sense $\left(\mathrm{H}^{2}\right)$ for yield and yield related traits are presented in Table 4. [24] categorized $\mathrm{H}^{2}$ estimates as low $(<40 \%)$, medium $(40-59 \%)$, moderately high $(60-79 \%)$, and very high $(\geq 80)$. For combined analysis estimated heritability values ranged from $52.3 \%$ for grain yield to $90.6 \%$ for days to heading. Very high heritability in broad sense was observed for days to heading $(90.6 \%)$ followed by days to mature $(86.6 \%)$, grain filling period $(85.3 \%)$, spike length $(84.8 \%)$, biomass weight $(81.8 \%)$, plant height $(80.9 \%)$, harvest index $(80.1 \%)$ and hectoliter $(80.1 \%)$. High heritability was obtained for number of kernel and medium heritability for grain yield. Very high heritability in broad implies the variation observed was mainly under genetic control and less influenced by the environment and the possibility of progress from selection. The obtained results agreed with results reported by $[12,17,25]$. 


\subsection{Estimates of Genetic Advance for Yield and Yield Related Traits}

Genetic advance as percent mean (GAM) was categorized as low $(0-10 \%)$, moderate $(10-20 \%)$ and high $20 \%$ and above according to [8]. Accordingly, combined location GAM ranged from $0.9 \%$ spike length to $15.9 \%$ for harvest index (Table 4). Low GAM was observed for days to heading $(2.9 \%)$, days to mature $(1.9 \%)$, grain filling period $(2.5 \%)$, plant height $(3.4 \%)$, spike length $(0.9 \%)$, number of kernel per spike $(5.4 \%)$, biomass weight $(5.5 \%)$, grain yield $(3.8 \%)$ and hectoliter weight $(2.6 \%)$ (Table 4$)$. This finding was agreed with the result of [10] who reported low genetic advance as percent of mean for the characters days to mature, plant height, number of kernel per spike, grain yield and hectoliter weight. However, high GAM values were reported by $[11,12,19]$ for biomass, grain yield and total number of tillers per plant which contradict with the present finding.

As [8] suggested the importance of considering both the genetic advance and heritability of traits simultaneously rather than considering them separately in determining how much progress can be made through selection.

In this study, for combined location high heritability accompanied with low genetic advance as percent of mean was observed for days to heading, days to mature, grain filling period, plant height, spike length, biomass weight and hectoliter weight (Table 4).

This may be because of predominance of non-additive gene action in the expression of this character. The high heritability of these traits was due to favorable influence of environment rather than genotypic and selection for these traits may not be rewarding.

Table 4. Estimates of mean, standard error, range, genotypic, phenotypic coefficient of variability, heritability in broad sense, genetic advance and genetic advance as percent of mean of yield and yield related traits across locations, in 2017.

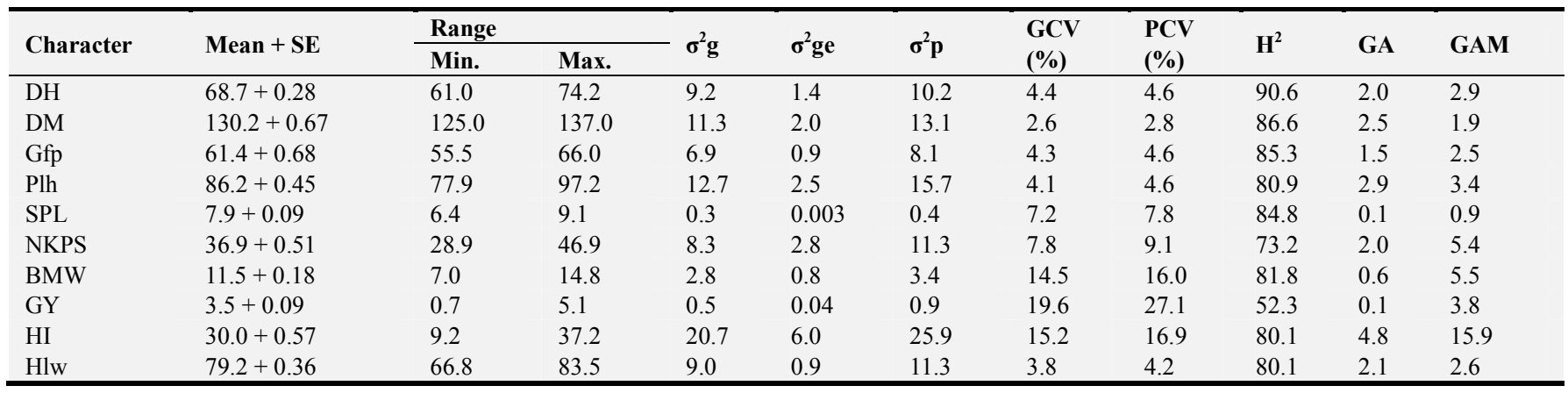

${ }^{\mathrm{a}} \mathrm{DH}=$ days to heading, $\mathrm{DM}=$ days to maturity, Gfp = grain filling period, $\mathrm{Plh}=$ plant height, Npt $=$ number of productive tiller, NSPS $=$ number of spiklet per spike, SPL = spike length in centimeter, NKPS = number of kernel per spike, BMW = biomass weight ton per hectare, GY $=$ grain yield in ton per hectare, HI $=$ harvest index in percentage, $\mathrm{TKW}=$ thousand kernel weight, Hlw $=$ hectoliter weight, $\mathrm{SE}=$ standard error, $\sigma^{2} \mathrm{p}=$ phenotypic variance, $\sigma^{2} \mathrm{~g}=$ genotypic variance, $\mathrm{GCV}=$ genotypic coefficient of variation, $\mathrm{PCV}=$ phenotypic coefficient of variation, $\mathrm{H}^{2}=$ heritability in broad sense, $\mathrm{GA}=$ genetic advance and $\mathrm{GAM}=$ genetic advance as percent of mean.

\section{Summary and Conclusion}

Thirty bread wheat genotypes were grown at Sinana and Agarfa to generate information on advanced bread wheat lines to assess the extent of genetic variability. Combined over locations ANOVA was carried out for yield and yield related traits. There were highly significant differences among genotypes for all traits. Highly significant location effects at $P<0.01$ were observed for yield and yield related except for harvest index which showed significant effect at $P$ $<0.05$ and grain yield non-significant location effect. This indicates the presence of variability for these characters among the tested genotypes and this would provide ample scope for selecting superior genotypes for further improvement of the traits in bread wheat.

In combined analysis, grain yield had high PCV and moderate GCV was observed for biomass weight, grain yield and harvest index. Phenotypic coefficient of variance (PCV) moderate for biomass weight and harvest index. Low GCV and PCV was observed for days to heading, days to mature, grain filling period, plant height, spike length, number of kernel per spike and hectoliter. The difference between GCV and PCV in this study were very small, implying the influence of environment on these characters were small. Result of combined over locations analysis of heritability estimates in broad sense $\left(\mathrm{H}^{2}\right)$ for yield and yield related traits revealed that, there was very high heritability estimate observed for days to heading, days to mature, grain filling period, spike length, biomass weight, plant height, harvest index and hectoliter. However, low genetic advance as percent of mean was observed for days to heading, days to mature, grain filling period, plant height, spike length, biomass weight and hectoliter weight. Finally, the presence of variability among the genotypes, performance of heritability and GAM in the tested traits of the genotypes confirmed possibility to increase wheat productivity. Hence, selection and hybridization on those genotypes can be recommended for farther yield improvement of bread wheat.

\section{Acknowledgements}

The study was financed by Oromia Agricultural Growth Program II and Oromia Agricultural Research Institute, Finfinne, Ethiopia. The authors are very grateful to individuals who participated in facilitating the field management, data collection and analysis. 


\section{References}

[1] Feuillet, C., Langridge, P. and Waugh, R. 2007. Cereal breeding takes a walk on the wild side. Trends in Genetics, 24: 24-32.

[2] Marcussen, T., Simen, R., Sandve, Heier, L., Spannagl, Pfeifer, M., Kjetill, S., Jakobsen, Brande, B. H., Wulff, Steuernagel, B., Mayer, F. X. and Olsen, O. D. 2014: Ancient hybridizations among the ancestral genomes of bread wheat. Science, 345: 6194.

[3] CSA (Central Statistical Authority). 2017. Agricultural sample survey 2016/17. Report on area and production of major crops for private peasant holdings, meher season. Statistical 584 (1), Central statistical agency, Addis Ababa, Ethiopia.

[4] Hawkesford, M. J., Araus, J., Park, R., Derini, D. C., Miralles, D., Shen, T., Zhang, J. and Parry. M. A. J. 2013. Prospects of doubling global wheat yields. Food and Energy Security 2: $34-48$.

[5] Khan, A. J., Azam, F. and Ali, A., 2010 Relationship of morphological traits and grain yield in recombinant inbred wheat lines grown under drought conditions. Pakistan Journal of Botany. 42 (1): 259-267.

[6] Kotal, B. D., Das, A., and Choudhury, B. K. 2010. Genetic variability and association of characters in wheat (Triticum aestivum L.) Asian journal of crop science, 2 (3): 155-160.

[7] Aremu, O. 2012. Exploring Statistical Tools in Measuring Genetic Diversity for Crop Improvement, Genetic Diversity in Plants, Prof. Mahmut Caliskan (Ed.), ISBN: 978-953-510185-7.

[8] Johnson, H. W., Robinson, H. F. and Comstock, R. E. 1955. Estimates of genetic and environmental variability in soybeans. Agronomy Journal 47: 314-318.

[9] Obsa Chimdesa. 2014. Genetic variability among bread wheat (Triticum aestivum L.) genotypes for growth characters, yield and yield components in Bore district, Oromia regional State. MSc Thesis Haramaya University, Ethiopia.

[10] Alemu Dabi. 2016. Estimation of genetic and phenotypic correlation coefficients and path analysis of yield and yield contributing traits of bread wheat (Triticum aestivum L.) Genotypes. International Journal of Natural Resource Ecology and Management, 1 (4): 145-154.

[11] Kifle Zerga, Firew Mekbib and Tadesse Dessalegn. 2016. Estimation of association among growth and yield related traits in bread wheat (Triticum aestivum. L) genotypes at Gurage Zone, Ethiopia. International Journal of Plant Breeding and Crop Science, 3 (2): 123-134.

[12] Berhanu Mecha, Wassu Mohammed and Yemane T. 2017. Genetic variability, correlation and path analysis of yield and grain quality traits in bread wheat (Tritium aestivum L.) genotypes at Axum, Northern Ethiopia. Journal of plant breeding and crop science 9 (10): 175-185.
[13] SARC (Sinana Agricultural Research Center). 2006. Annual report. pp. 1-50.

[14] Burton, G. W. and De vane, E. H. 1953. Estimating heritability in Tall Fescue (Festuca arundinacea) from replicated clonal material. Agronomy Journal, 45: 487-488.

[15] Allard, R. W. 1960. Principles of plant breeding John Willey and Sons Inc. New York. pp 430.

[16] Idrees, N. and Khan, M. I. 2009. Design improvement using uniformity trials experimental data. Pakistan Journal of Agricultural Science, 46 (4): 2076-0906.

[17] Tesfaye Wolde, Firdisa Eticha, Sentayehu Alamirew, Ermias Asefa and Dargicho Dutamo 2016. Genetic variability, heritability and genetic advance for yield and yield related traits in durum wheat (Triticum durum L.) accessions. Sky Journal of Agriculture Research, 5 (3): 42-47.

[18] Adhiena Mesele. 2015. Genetic variability and association among seed yield and yield related traits in bread wheat (Triticum aestivum L.) genotypes at Ofla District, Northern Ethiopia,. M. Sc. Thesis, Haramaya University, Haramaya, Ethiopia.

[19] Almaz Bedada. 2017. Genetic variability and association of yield and yield related traits in advanced bread wheat (Triticum aestivum L.) lines in eastern Ethiopia. Msc Thesis at Haramaya University, Ethiopia.

[20] Gezahegn F., Sentayehu Asefa and Zerihun Taddese. 2015. Path coefficient and correlation studies of yield and yield associated traits in bread wheat (Triticum aestivum L.) genotypes at Kulumsa Agricultural Research Center, South East Ethiopia. Journal of Food Science and Quality, ISSN 2224-6088 Vol. 38

[21] Navin, K., Shailesh, M. and Vijay, K. 2014. Studies on heritability and genetic advance estimates in timely sown bread wheat (Triticum aestivum L.). Journal Bioscience Discovery, 5 (1): 64-69.

[22] Deshmukh, S. N., Basu, M. S. and Reddy, P. S. 1986. Genetic variability, character association and path coefficient analysis of quantitative traits in Viginia bunch varieties of groundnut. Indian Journal of Agricultural Science, 56: 516-521.

[23] Arati, Y., Hanchinal, R. R., Nadaf, H. L., Desai, S. A., Suma, B. and Rudra, N. V. 2015. Genetic variability for yield parameters and rust resistance in $F_{2}$ population of wheat (Triticum aestivum L.). International Quarterly Journal of Life Science, 10 (2): 707-710.

[24] Pramoda, H. P. and Gangaprasad, S. 2007. Biometrical basis of handling segregation population for improving productivity in onion (Allium cepa L.). Journal of Asian Horticulture, 3 (4): $278-280$.

[25] Rajput, S. R. 2018. Correlation, path analysis, heritability and genetic advance for morpho-physiological character on bread wheat (Triticum aestivum L.). Journal of Pharmacognosy and Phytochemistry, 7 (2): 107-112. 